\title{
Rivers Conservation Challenges and Opportunities: A Case Study of BundelKhand, Madhya Pradesh, India
}

\author{
Hemant Pathak* \\ Department of Chemistry, Indira Gandhi Government Engineering College, India
}

Submission: December 13, 2017; Published: December 21, 2017

*Corresponding author: Hemant Pathak, Department of Chemistry, Indira Gandhi Government Engineering College, India, Tel: 91-9770385716;

Email: hemantp1981@yahoo.co.in

\section{Abstract}

Bundelkhand, MP (Population around 7.3 millions) is facing huge scarcity of water despite the presence of various big rivers like Betwa, Ken, Dhasan, Sonar and their various other tributaries, has become a synonym for drought, unemployment and perennial water stress. Agriculture in Bundelkhand is rain fed, diverse, complex, under-invested, risky and vulnerable. In addition, extreme weather conditions, like droughts, shortterm rain and flooding in fields add to the uncertainties and seasonal migrations. River channels and its adjoining areas have long been exploited for construction grade aggregates like sand and gravel, indiscriminate sand mining from rivers and its basin areas imposes many harmful effects on the environment and impacted upon geologic and geomorphic settings, river side, resource availability, climatic conditions, etc. in order to mitigate the impact of sand mining on the environment, a scientific evaluation assessment is a pre-requisite for framing sustainable development strategies for the mining-hit areas. River management is key to socio-economic sustainability. There is a need to develop a locally relevant policy for sustainable development. Every year huge migration occurs due to looming food and livelihood crisis. Sustainable development is a broad and complex subject but has no alternative, especially when we look at challenges and miseries of Bundelkhand water scarcity. River Water management need to be undertaken as a mission for socio-economic uplift and to remove disparities.

Keywords: Bundelkhand; River Water Management; Sustainable Development

\section{Introduction}

Rivers are amongst the most important ecosystems for biotic and abiotic components, it is a essential services for mankind, fighting from various anthropogenic activities on Earth. Major source of water in Bundelkhand region's rivers fed by monsoon rain. In Bundelkhand Rivers are threatened by various problems, including deforestation, urbanization, overexploitation of resources, over industrialization and consequently reception of an increasing variety of chemical pollutants and biodiversity depletion [1]. Scarcities of water escalate in this region, creating serious problems for local people and the environment.

Bundelkhand Population reached around 7.3 million and projected to rise to 8 million by 2030. Almost $80.5 \%$ of Bundelkhand's population lives in rural areas (2011 census), and most of this population is dependent on agriculture, shepherd and Fishing for livelihood. Approximately $60 \%$ of the populations are workers, and of them, nearly $60 \%$ are working as cultivators and agricultural laborers [2].

\section{Methodology and Study Area}

The Betwa River contributes around $50 \%$ of the water available in the Bundelkhand upland and Bundelkhand plain subregions; the Ken contributes another 25\%. The Betwa, Ken, Pahuj, Bina, Sonar, Bewas, Sind and Dhasan are prominent for irrigation in the region. Their seasonal variations however are very large.
In the present study data from two important Rivers and their several tributaries were considered. Betwa River - originates from groundwater re $\neg$ charge near Jhiri village in the Vindhyas; Ken River - Ken River originates near village Ahirgawan on the northwest slopes of Barner Range in Jabalpur district. Case for a current period analyzed [3].

\section{Challenges associated with Betwa River}

Total length of the Betwa River from its origin to its confluence with Yamuna is $573 \mathrm{~km}$ long with a total catchment area of 46580 Sq.Kms. Rampant violations of environmental norms by industries and gross negligence on the part of regulatory authority are the main cause of river pollution [4]. The River Betwa plays a significant role in the human life of the Bundel khand region. This river is mainly polluted by the industrial and urban wastes from industrial areas nearby, Bhopal (Capital of Madhya Pradesh) viz. Mandideep and other big populated districts like Vidisha and Raisen. Betwa receives a heavy BOD and COD loads from urban and industrial sources by anthropogenic activities. The dis $\neg$ charge from Bhopal alone is approximately 11,000 cum of wastewater, which has a BOD load of $1200 \mathrm{~kg}$ per day. The water in the upper reaches of the river industrial estates in Bhopal and Raisin dis $\neg$ tricts let out their effluents into the Betwa, is polluted with a heavy load of inorganic constituents. 
The main source of pollutants generating both organic and inorganic waste was found to originate from illegal agriculture activity, unsustainable development and household activities of indigenous people. In 1997, NEERI Nagpur monitored on river water quality parameters, revealed that the water quality of the river is very bad that it cannot be used even for irrigation purposes [5]. The Betwa River has been selected by the National River Conservation Plan (NRCP) for cleaning and pollution control. These days Betwa river is dying a slow death by the sand mafia has plundered it in the region, where the illegal sand mining business is worth hundredth billion per year. The Betwa carries heavy granules that are useful in building as well as road construction [6]. This river that flows from the Vindhyan range was once the home of a variety of aquatic fauna. Agriculture and fishing culture flourished in its river basin area. Now, the 358-kilometre stretch of the river flowing through Lalitpur, Jhansi, Jalaun and Hamirpur is fast turning into a barren area as earthmovers extract sand from the river bed.

\section{Socio-Economical, Environmental Importance of Betwa River}

Betwa is the lifeline for the region through which it flows. Betwa Rivers with its tributaries Chureigaura, Bhakha, Barva, Dhasan and Jamini are the bloodstreams which gives life to the Bundelkhand. The Betwa has been dammed at Matatila and multipurpose interstate Rajghat Dam has been recently built for generation of electricity as well as irrigation. It is the major source of irrigation for the area known for the production of high quality wheat, gram and soybean in the country [7]. Betwa was the home of various aquatic species like crocodiles, dolphins and otters, but now these species are hardly seen in the area. Betwa play a significant role in many aspects of human life which has been guiding the socio-economic-politico and cultural attributes of the human, who were closely associated with the rivers in the initial phases of the cultural evolution.

\section{Challenges associated with Ken River}

Total length of Ken River is 427 kilometers has an overall drainage basin of 28,058 km2, out of which 12,620 km2 belong to Sonar River its largest tributary, whose entire basin lies in Madhya Pradesh; and along its 427 kilometers course it receives water from its own tributaries such as Bawas, Dewar, Kaith and Baink on the left bank, and Kopra and Bearma of the right [8]. The river, as a tourist place is losing its prominence. Urbanization along with the formation of factories and emerging thermal power projects have caused massive pollution and contamination of the river over the ages and this has made it typically unfit for any kind of domestic usage.

\section{Socio-economical, Environmental importance of Ken River}

Ken River is very important for drinking, irrigation, Tourism, Transportation and rare fauna and flora. Some of the attractive tourist places situated on this river are the Raneh falls and the Ghariyal Sanctuary. The river also crosses across the Panna
National Park which also is a well known tourist attraction. Finally, this river is most famous for its rare Dendritic Agate stone. Ken determines many factors in the society like population density, demand and supply of staple foods, food security etc. All these characteristics makes the importance of Ken in the economy of the BundelKhand and it is the significance of river which is the basic frame for the economy of a nation like India where agriculture is the main livelihood activity of the majority of the Indians with ever growing population [9]. It provides drinking water to 3 million people, and provides foods, irrigations, transportations and important for hunters, anglers, boaters and other outdoor enthusiasts with exceptional recreational opportunities.

\section{Sonar River: Challenges and Socio-economical, Envi- ronmental importance}

The River Sonar is a rain-fed river. Its overall length is more than $250 \mathrm{~km}$. It flows south to north; It drains an approximately 12000 square kilometer area of the southern boundary of Bundelkhand. The natural water bodies are continuously getting contaminated by the discharge of sewage, industrial and other wastes originated from anthropogenic activities. The water quality and pollution of surface water disrupts algal communities which can affect the entire aquatic food web that will result is a serious threat to life. Few government project are planned on the river for provide water for agriculture and electricity production. Pancham nagar project are planned on Bewas river main tributary of the Sonar River for provide water by canal for agricultural use and provide full amount water for former dry lands. Another project is Saksuma Dam for production of electricity on main river Sonar [10].

\section{Proposed Conservation strategies for Rivers}

The rising issue in Bundelkhand is that there is no well established water management plan. It is important to implement water conservation and management in rainfall season not drought times. The government has not promoted awareness for river conservation and cleanliness; people have lost their traditional respect to save their water resources. To applied modern technology like remote sensing and GIS (geographical information system) to carry out a survey and the problem is not just deficit rainfall but the adaptive capacity should be developed by farmers.

Strategies may include:

a. Reconnecting the river with its flood plain.

b. Reforesting along rivers.

c. Creates strict law and regulation on effluent discharge.

d. Working with farmers to identify sustainable approaches to land use.

e. Acquiring land and conservation easements.

f. Working with landowners on voluntary River management practices, 
g. Strict bane on unlawful Mining's

h. Rigid Law to Conserve flora and Fauna, and

i. Building support for the river at both the highest levels of government and the community level.

\section{River networking}

In the era of climate change; river networking is the need of time for development. Government of India has developed a new National Water Policy which claims that water is a prime natural resource, a basic need and a precious national asset. In Bundelkhand Ken-Betwa Linking Project approach to their last stage to generate electricity and proper drinking water supply [11]. This project also promotes national integration and a fair sharing of the country's natural water wealth also shows and promises a great concern for water conservation and optimum use of available water resources. Farmers migrated and sold their livestock as they are unable to provide an adequate drinking water supply for their livestock. Networking prove to be important to increased in the crop production and livestock output. Groundwater recharge and irrigation will increase in and outside the command area, which will enable availability of water to the fields, villages, towns and industries of this backward area throughout the year.

\section{Results and Discussion}

Evaluation of different aspects of study area revealed that the intensity of pollution increased as the rivers was subjected to sewage and industrial waste. In order to manage the pollution load of River Betwa, Ken and their tributaries, it is recommended that various methods of sewage industrial waste treatment should be used before disposal of effluents. This is a study to aware the people how they have contaminated the source of life, facing many changes due to the development of urbanization and industrial evolution [12]. Traditional knowledge of water conservation has been lost in the region past many years. Need of communityoriented River management practices hold the key to the region's water and agrarian problems. Throughout Bundelkhand, women spent several hours per day to collect drinking water. Existing management policies including national water resources legislation, community based natural resource management schemes, and the protected area network that now epitomizes the
Bundelkhand rivers conservation paradigm cannot adequately curb most impacts.

Riverine ecology suffering from dramatic decreases that threaten the functioning of these ecosystems and the services and benefits. River conservation is the crucial issues to understanding of societal needs and policymakers. Due to River water scarcity farmers in Bundelkhand faced a famine-like situation after deficient rainfall in 2014 and 2015, but that is not all. The region has faced an unending spell of natural disasters continuous drought between 2003 and 2010 floods in 2011, a late monsoon and deficit rain in 2012 and 2013; and then the droughts. Bundelkhand Rivers ecosystems are being irreversibly disturbed because of increased anthropogenic activities. As more water is withdrawn and consumed for human uses. Scarcity of freshwater results from the unequal distribution, mismanagement of water by peoples and River water pollution that makes water unusable.

\section{Conclusion}

Rivers are the fastest ecosystems to recover from disturbance, and it is possible to restore them to healthy states. There is an urgent need to take Socio-economic, environmental concerns related to River water management so a very detailed hydrological, geological, meteorological and environmental analysis of the each River and their tributaries would be imperative in the benefit of Bundelkhand (victim of recurrent drought), India. As the conventional state-sponsored river conservation programmes have focused on the main stem of the rivers ignoring the tributaries, it is essential to the management of key tributaries like Sonar River. Since the studies aims to attention of Government of India on the ecological health of the River, it is important that the strategies implemented under each component of the programme are complementary to each other, with synergies being built between the components. There is an urgent need to shift the Rivers conservation paradigm, broadening its current forest-centric focus to encompass the freshwater ecosystems that are vital components of the basin.

\section{References}

1. https://en.wikipedia.org/United_Nations_Environment_Programme.

2. https://www.conserve-energy-future.com/causes -and-effects-ofenvironmental-pollution.php

3. UNO's report on e-Waste released in Geneva in December, 2017.

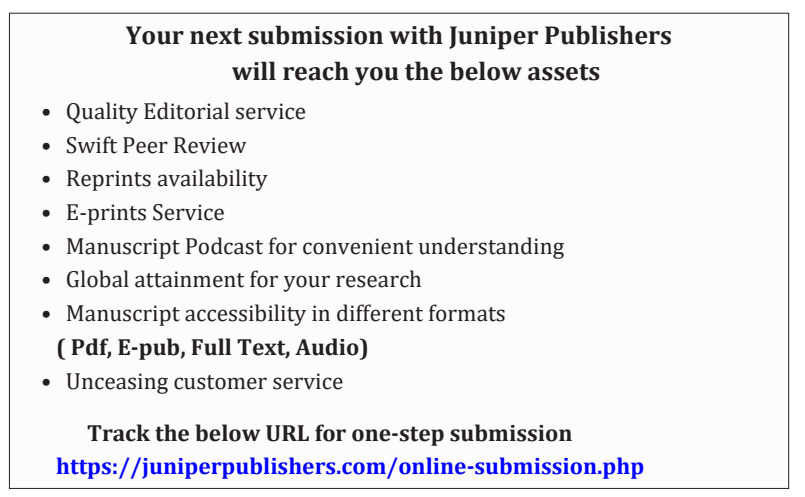

